\title{
Intellectual Structure of Accounting Research: A Historical Review on the Journal of Accounting Organization Society
}

\author{
Alper Erserim ${ }^{1}$ \\ ${ }^{1}$ Faculty of Business Administration, Mugla Sttkı Kocman University, Muğla, Turkey \\ Correspondence: Alper Erserim, Faculty of Business Administration, Mugla Sttk1 Kocman University, Muğla, \\ Turkey.
}

Received: February 6, 2016

Accepted: February 19, 2016

Online Published: February 28, 2016

doi:10.5430/afr.v5n2p1

URL: http://dx.doi.org/10.5430/afr.v5n2p1

This study was presented as a draft paper at the 11th. International Accounting Conference held in Istanbul between the dates of 31 October and 2 November 2014.

\begin{abstract}
The Journal of Accounting Organization Society (AOS) focuses on the relationship between accounting and processes of human behavior and organizational structure. In addition, the journal aims to address all aspects of the relationship between social and political environment change in terms of business with accounting. (Note 1) This is one of the primary reasons for choosing this journal as the study subject. Moreover, AOS ranked first in the list of accounting journals and fourth out of 45 business school journals and according to the Financial Times (Note 2). In this study, the structure of accounting research has been studied based on the AOS journal. This study specifically examines the AOS between the years 1990-2014.

The purpose of this study is to examine general approaches to the accounting research in the context of this journal for the last quarter of this century by examining the reference patterns of studies published in the AOS over the last 25 years. Such a type of situation assessment can contribute to understanding current developments in the international accounting literature, observing the interaction between accounting and other disciplines and understanding general trends in accounting research.

In this context, citation analysis was done for the studies in AOS and has attempted to put forward prominent reference sources and authors of these sources. The analysis further explains the impact of other journals on the articles' references published in the AOS.
\end{abstract}

Keywords: Accounting research, Intellectual structure, Citation analysis

\section{Introduction}

All the information generated in the social sciences can be implemented in real life problems to the extent supported by statistical and mathematical based measurement techniques as in other fields. The main reference point to understand development of accounting research is especially academic journals published periodically (Gökkurt, 1998: 22).

It is required to monitor publications periodically and form an inventory for these publications to understand sub-fields of social sciences. As a result, studies were conducted recently under universities' Information and Records Management Departments to find out what scientific information collectively produced. The reported results of scientific publications are important in science and technology policy determination and are an indispensable indicator as it finds place to itself. The effectiveness of scientific publications has usually been demonstrated by bibliometric studies. It is a well-known fact that bibliometric research conducted in this regard uses the citation indices as data sources. At same time information derived from citation indices are used to evaluate scientific publications of science and technology policy documents (Al, 2008: 3, 4).

International databases have developed a variety of tools for measuring the performance of publications. Important information related to the Web of Science citation database can be documented as most cited papers, impact factors of the journals and performances of authors by developed tools to analyze citations. However, a publication must be 
present in periodicals and scanned in databases to be included in the information provided by the database. Therefore, publications such as book/book chapters that are not included in the reference pool and non-scanned papers in databases are excluded from the analysis of those citation analysis tools. Sometimes the field's most important works can be a book or publication from other fields. For this purpose, all of the reference source of the publications must be evaluated to determine main referenced studies.

In this context, citations in the journal of Accounting, Organizations and Society (AOS) are examined and all of the references are included in the research. The question of this research is: What is the intellectual structure of the main reference sources that shapes the accounting research field? Additionally these questions are asked respectively, how were the main references distributed periodically? Which works fed the journal as a reference source? What are the studies forefronts from other fields?

This study is part of a larger research project. As part of ongoing research, bibliometric analysis is performed on the references published in accounting journals listed in the Financial Times' list of the top 45 business administration journals. These journals are as follows: Accounting, Organizations and Society; Accounting Review; Contemporary Accounting Research; Journal of Accounting and Economics; Journal of Accounting Research and Review of Accounting Studies. In the later stages of the analysis, publications of these journals will be examined by the citation and co-citation analyses from the beginning of their publication to the most recent publication. In this study, as part of the project, citation analysis was conducted by taking into account the weights of the studies published in the AOS and the most cited journals and authors are subsequently determined.

The following section briefly reviews the considerable studies related to the citation analysis and its application on accounting studies in the literature. Methodology of the study, analysis techniques, and data are introduced in section three. Section four discusses the results of the citation analysis conducted and provides some important authors and publications as listed according to the results. In the last section, the study is concluded with a general overview.

\section{Literature Review}

One of the first studies on citation analysis conducted in the literature was made by McCrae in 1974. In the study, the relationship between accounting systems and information systems has been examined through the publications of 17 journals during 1968-1969. Hofstedt (1976) examined the interaction between accounting and other disciplines under the title of behavioral accounting research and contributed to the discussion of citation analysis in this accounting field. A study conducted by Brown et al. (1985) examined the effect of important journals that published in the field and is found in the journal of "Contemporary Accounting Research" (CAR). The same topic applied on the journal of AOS which is also the subject of this study (Gardner et al., 1987). In the study, the impact of AOS articles that published between 1976 and 1984 on the studies published between 1985 and 1986 were analyzed.

According to Bonner et al. (2006) ranking of the accounting journals was determined by survey and citation techniques which led them not to consider subfields of accounting literature properly. As a result of this conclusion, Chan et al (2009) considers the dissertations completed during 1999-2003 and ranks the top journals according to their specialty in the accounting field. Chan and Liano (2009) also determined the most influential journals, articles, institutions and researchers in the accounting field by using a threshold citation analysis technique. The Journal of Accounting Research, the Journal of Accounting and Economics and Accounting Review were determined as the most influential journals while Richard G. Sloan, Robert E. Verrechia and Paul M. Healy were the most influential researchers in the accounting field.

Tahai and Rigsby (1998) investigate the durability of research in the accounting literature by using gamma distribution to determine mean, median and mode for citation age of those studies. Authors concluded that the mean number of citation years is nine and Accounting, Organization and Society, the subject of this study is among the most influential four accounting journals according to their periodical track records.

Solomon and Trotman (2003) examined the author's profile of AOS compared to other journals in the field according to some evaluation criteria. Just et al. (2009) examined number of 2578 study in total that published in leading journals including AOS during the years of 1990-2007 and authors classified the 50 major works located in the journals according to their periods.

\section{Method}

One of the most important purposes of scientific research is to impact other researchers and the field itself. It should be noted that citations play an important role just in measuring the impact of publications, thus constituting a subset of scientific authority. Some studies are referenced not just for the direct intellectual impact they have but also for the legitimacy they give to the topic. At the same time, it is observed that authors have the tendency to prefer theoretical, 
conceptual and review studies compare to the experimental and observational studies (Peng and Zhou, 2006: 491).

Citation analysis research draws a lot of interest in recent years and issues such as author efficiency, the use of publications, and the aging of literature are discussed in these studies. In this context, citation analysis research, for example, is helping to create core journal collection, to determine how long the resources are used, the most commonly used sources, and who the most productive researchers are in a particular topic. The findings of citation analysis are both used to evaluate scientific research activities and the benefit to library collections management and development ( $\mathrm{Al}$ and Tonta, 2004: 21).

This study is a literature research that uses bibliometric technique as an analysis method. Bibliometric analysis indicates the collecting, processing and analyzing of data obtained from scientific publications (Verbeek et al., 2002: 181). bibliometric analysis- based approach is accepted as objective to the evaluation of research in a particular field (Acedo and Casillas, 2005).

The sum of 63, 628 citations obtained from a set of 880 articles published during 1990-2014 in the AOS journal have been examined and the main framework of the publications determined. Table 1 shows the number of articles and citations periodically considered in this study. As seen in the table, $41-\%$ of the articles included in this study belong to the period of 1990-1999. The percentage of total citations obtained from these studies in this period was 36- \%. Additionally, 42- \% of the articles included in this research belong to the period of 2000-2009 and their share of the citations out of all the studies is $43-\%$. Finally, $17-\%$ of articles used in the study cover the last five years of the AOS journal and their share of the citations in these articles from that period is $21-\%$.

Table 1. Number of articles and citations

\begin{tabular}{lll}
\hline Observation Period & Sum of Articles (\%) & Sum of Citations (\%) \\
\hline $1990-1999$ & $359(41 \%)$ & $22981(36 \%)$ \\
$2000-2009$ & $367(42 \%)$ & $27151(43 \%)$ \\
$2010-2014$ & $154(17 \%)$ & $13496(21 \%)$ \\
Total & 880 & 63628 \\
\hline
\end{tabular}

In the study, prominent articles published in the AOS over the last 25 years are determined by using citation analysis as one of the bibliometric techniques. Additionally, other journals' contributions to AOS with their weight are determined. Moreover, most cited authors' publications over the last 25 years are also determined. The main findings mentioned above are presented in the following sections.

\section{Results}

The Web of Science and Science Direct databases were used to examine the publications of the AOS journal. According to data obtained from these databases, this study covers the 25 year periods from 1990-2014. During this period, the number of publications in the journal is 880 and number of references belonging to these articles is 63628 . During the examination of the AOS journal, article and research notes are included while editorials, book reviews, post adjustments, and call for paper have not been taken into account.

The results of the research information obtained from databases were transferred to Excel and analyzed. Firstly, most referenced publications are listed in Table 2. Next, the books and journals mostly feeding the AOS journal as sources were determined and also shown in Table 3. Finally, the authors who come to the forefront in the AOS journal are shown in Table 4.

According to the finding of most cited articles of the AOS journal, the 1980's had significant differences compared to the other periods of publications. The mean year of the most cited publications is 1984; the newest publication in the list belongs to the year 1992 (Robson), while the oldest publication was in 1977 (Meyer, Foucault and Magali). It is possible to see from the weights of the periodicals in the list that those periodicals comprise 12 of the total 20 publications.

When the publications are examined according to content, books like Science in Action, The Constitution of Society, and Psychometric Theory in the list showed that the journal of AOS can be defined as a multi-disciplinary periodical. Psychometric Theory is a measurement- oriented statistical methodology book. The reason behind the rise of Science in Action by Latour can be considered under the actor-network theory (individuals, technology, nature, theories, opinions, and beliefs form a network to create a new field) (Justesen and Jan Mouritsen: 2011). In addition, it is possible to say that culture studies decrease respectively towards the years including and after 2010's (Hofstede, 1979). Numerous findings regarding the content can be made from the list below. Studies published in the fields of 
account management, sociology, and psychology are among the core studies in the list below and it is possible to say that these studies have not lost importance during any of the periods. Three of the studies belong to the field of organization theory. The seventh and tenth articles are the pioneering studies of neo-institutional theory in the field of organization theories (Özen, 2007: 237-239). The last article in the list focuses on the effect of national culture on the organizations also providing a legitimating effect on organizational culture issues that take place in the field as a sub-organization theory (Hatch and Cunliffe, 2006: 181).

Table 2. Most Cited 20 Studies in AOS Journal

\begin{tabular}{|c|c|c|c|c|c|c|}
\hline \multirow[b]{2}{*}{$\begin{array}{l}\text { R(Note } \\
4)\end{array}$} & \multirow{2}{*}{$\begin{array}{l}\text { Most Cited } 20 \text { Studies in the AOS Journal During 1990-2014 } \\
\qquad \text { Publication Information }\end{array}$} & \multicolumn{5}{|c|}{ Periods (Note 3) } \\
\hline & & $\begin{array}{c}\mathrm{D}(\text { Note } \\
5)\end{array}$ & 1 & 2 & 3 & Total \\
\hline 1 & $\begin{array}{l}\text { Peter Miller, Ted O'Leary, Accounting and the Construction of The Governable } \\
\text { Person, Accounting, Organizations and Society, Volume 12, Issue 3, } 1987 .\end{array}$ & 1041 & 62 & 41 & 16 & 119 \\
\hline 2 & $\begin{array}{l}\text { Anthony G. Hopwood, The Archeology of Accounting Systems, Accounting, } \\
\text { Organizations and Society, Volume 12, Issue 3, } 1987 .\end{array}$ & 1050 & 60 & 40 & 14 & 114 \\
\hline 3 & $\begin{array}{l}\text { Stuart Burchell, Colin Clubb, Anthony Hopwood, John Hughes, Janine Nahapiet, } \\
\text { The Roles of Accounting in Organizations and Society, Accounting, Organizations } \\
\text { and Society, Volume 5, Issue 1, } 1980 .\end{array}$ & 1192 & 53 & 36 & 23 & 112 \\
\hline 4 & $\begin{array}{l}\text { Andrew Abbott, The System of Professions: An Essay on the Division of Expert } \\
\text { Labor. By. Chicago: University of Chicago Press, } 1988 .\end{array}$ & 7492 & 34 & 30 & 20 & 84 \\
\hline 5 & $\begin{array}{l}\text { Bruno Latour, Science in Action: How to Follow Scientists and Engineers Through } \\
\text { Society Harvard University Press, } 1987 .\end{array}$ & 16981 & 18 & 43 & 15 & 76 \\
\hline 6 & $\begin{array}{l}\text { Stuart Burchell, Colin Clubb, Anthony G. Hopwood, Accounting in its Social } \\
\text { Context: Towards A History of Value Added in The United Kingdom, } \\
\text { Accounting, Organizations and Society, Vol. 10, Issue 4, } 1985 .\end{array}$ & 563 & 34 & 26 & 7 & 67 \\
\hline 7 & $\begin{array}{l}\text { Meyer, J.W. and Rowan, B. 'Institutional Organizations: Formal Structure as } \\
\text { Myth and Ceremony', American Journal of Sociology 83: } 1977 . \\
\text { Keith W. Hoskin, Richard H. Macve, Accounting And The Examination: A }\end{array}$ & 17182 & 33 & 19 & 13 & 65 \\
\hline 8 & $\begin{array}{l}\text { Genealogy Of Disciplinary Power, Accounting, Organizations and Society, Vol. 11, } \\
\text { Issue } 2,1986 .\end{array}$ & 525 & 33 & 26 & 5 & 64 \\
\hline 9 & $\begin{array}{l}\text { Foucault, M. Discipline and Punish: The Birth Of The Prison, New York, Random } \\
\text { House } 1977 .\end{array}$ & 41335 & 29 & 21 & 11 & 61 \\
\hline 10 & $\begin{array}{l}\text { DiMaggio, P.J. and Powell, W.W. "The Iron Cage Revisited: Institutional } \\
\text { Isomorphism and Collective Rationality in Organizational Fields." American } \\
\text { sociological review } 48 \text { (2): } 1983 .\end{array}$ & 26631 & 24 & 20 & 11 & 55 \\
\hline 11 & $\begin{array}{l}\text { Alistair M. Preston, David J. Cooper, Rod W. Coombs, Fabricating budgets: A } \\
\text { study of the production of management budgeting in the national health service, } \\
\text { Accounting, Organizations and Society, Volume 17, Issue } 6 \text {, August } 1992 .\end{array}$ & 330 & 18 & 28 & 7 & 53 \\
\hline 12 & Magali Sarfatti, The Rise of Professionalism, Univ. of California Press, Jan 1, 1977. & 4741 & 25 & 17 & 7 & 49 \\
\hline 13 & Nunnally, J. C, Psychometric Theory, New York: McGraw Hill, 1978. & 60097 & 17 & 22 & 10 & 49 \\
\hline 14 & Anthony Giddens, The Constitution of Society, Univ. of California Press, 1986. & 29009 & 20 & 15 & 12 & 47 \\
\hline 15 & $\begin{array}{l}\text { Peter Armstrong, The Rise of Accounting Controls in British Capitalist } \\
\text { Enterprises, Accounting, Organizations and Society, Volume 12, Issue 5, } 1987 . \\
\text { Keith Robson, Accounting Numbers As "Inscription": Action at A Distance and }\end{array}$ & 324 & 32 & 12 & 2 & 46 \\
\hline 16 & $\begin{array}{l}\text { The Development of Accounting, Accounting, Organizations and Society, Volume } \\
\text { 17, Issue 7, October } 1992 .\end{array}$ & 367 & 5 & 27 & 12 & 44 \\
\hline 17 & $\begin{array}{l}\text { Watts, Ross L; Zimmerman, Jerold L., Positive Accounting Theory, } \\
\text { 1986,Prentice-Hall }\end{array}$ & 4785 & 27 & 12 & 5 & 44 \\
\hline 18 & $\begin{array}{l}\text { Lawrence A. Gordon, V.K. Narayanan, Management accounting systems, } \\
\text { perceived environmental uncertainty and organization structure: An empirical } \\
\text { investigation, Accounting, Organizations and Society, Volume 9, Issue } 1,1984 \text {. }\end{array}$ & 594 & 17 & 24 & 1 & 42 \\
\hline 19 & $\begin{array}{l}\text { Peter Armstrong, Changing management control strategies: The role of } \\
\text { competition between accountancy and other organizational professions, } \\
\text { Accounting, Organizations and Society, Volume } 10 \text {, Issue } 2,1985 \text {. }\end{array}$ & 317 & 24 & 14 & 2 & 40 \\
\hline 20 & $\begin{array}{l}\text { Geert Hofstede, Culture's consequences: International differences in } \\
\text { work-related values, Sage Publications, } 1980 .\end{array}$ & 26288 & 20 & 17 & 3 & 40 \\
\hline
\end{tabular}


Journals of references that are used in the AOS journal are investigated and the most frequently used 20 journals are listed in Table 3. The 20 journals listed below constitute almost one- third of the all references (63628) examined in the study. It can be concluded that an AOS journal publication substantially feed its own publications and is on the top of the journal rankings.

The research showed that journals of management sciences in particular were weighted heavily on the list. Six of the 20 journals (Administrative Science Quarterly, Harvard Business Review, The Academy of Management Journal, Strategic Management Journal, Academy of Management Review, and the Journal of Applied Psychology) listed below are the leading journals in the field of management (Podsakoff et al. 2008: 649). The strategic management discipline started earning the distinction as of being a scientific discipline recently (Barca, 2005: 34) and it is interesting that the AOS journal shows sensitivity to the rise of the Strategic Management Journal one of the most important periodicals in sub-fields of management discipline in the 2000s. Additionally, the American Journal of Sociology is one of the most cited journals by AOS. This shows that AOS continues to be at publication of its own nature. As stated in the introduction of the study, the AOS journal focuses on the "relationship between human behavior, structures of organization process and accounting".

Critical accounting, management accounting and auditing journals occupy a great deal of space when the accounting field is examined. Findings demonstrate that the number of critical accounting and sociology field journals is increasing by period in recent years. Some considerable points not included in the list are that law and organizational behavior journals are also found among the important references of AOS articles. "Organizational Behavior and Human Decision Processes", "Laws of Market" and "Law Policy" journals are among the first thirty journals with their citation quantities 247 and 147 respectively.

Table 3. Most Cited Journals Periodically in AOS Journal

\begin{tabular}{llcccc}
\hline \multicolumn{2}{c}{ Most Cited 20 Journals In AOS Journal During } & 1990-2014 & & \\
Rank & \multicolumn{1}{c}{ Journals } & 1990-1999 & $2000-2009$ & $2010-2014$ & Total \\
\hline 1 & Accounting, Organizations and Society & 2405 & 3610 & 1723 & 7738 \\
2 & The Accounting Review & 873 & 847 & 397 & 2117 \\
3 & Journal of Accounting Research & 631 & 582 & 213 & 1426 \\
4 & Administrative Science Quarterly & 457 & 330 & 152 & 939 \\
5 & Critical Perspectives On Accounting & 124 & 307 & 239 & 670 \\
6 & Accounting, Auditing \& Accountability Journal & 118 & 320 & 212 & 650 \\
7 & Academy of Management Review & 180 & 275 & 160 & 615 \\
8 & The Academy of Management Journal & 167 & 282 & 141 & 590 \\
9 & Journal of Management Accounting Research & 55 & 334 & 92 & 481 \\
10 & American Journal of Sociology & 136 & 137 & 162 & 435 \\
11 & Management Accounting Research & 89 & 240 & 105 & 434 \\
12 & Accounting, Business \& Financial History & 80 & 201 & 84 & 365 \\
13 & Journal of Accounting and Economics & 57 & 195 & 104 & 356 \\
14 & Contemporary Accounting Research & 41 & 146 & 137 & 324 \\
15 & Management Accounting Quarterly & 37 & 251 & 30 & 318 \\
16 & Auditing A Journal of Practice \& Theory & 111 & 85 & 110 & 306 \\
17 & Journal of Accountancy & 191 & 92 & 20 & 303 \\
18 & Strategic Management Journal & 38 & 206 & 58 & 302 \\
19 & Harvard Business Review & 135 & 108 & 50 & 293 \\
20 & Journal of Applied Psychology & 119 & 124 & 49 & 292 \\
& & 6044 & 8672 & 4238 & 18954 \\
\hline
\end{tabular}


Most cited authors determined in the study and 20 of them are presented below in Table 4 . When creating this list, the author of the studies is taken into account according to data provided by databases, and the other authors in the same studies are ignored. Two authors on the top of the list are Hopwood A. G. and Peter Miller, major contributors to the AOS journal. Although Foucault Michel, Latour Bruno and Giddens Anthony are not directly related to the field of accounting, they shape the accounting field by their work. The impact of Foucault's work on accounting research (Armstrong, 1994) can be investigated in-depth. Furthermore, the number of citations to Hofstede decreases periodically as a reflection of the decline in cultural studies.

Table 4. Most Cited 20 Authors Periodically in AOS Journal

\begin{tabular}{llcccc}
\hline \multicolumn{5}{c}{ Most Cited 20 Authors In AOS Journal During 1990-2014 } \\
$\mathrm{R}$ & Author Name & $1990-1999$ & $2000-2009$ & $2010-2014$ & Total \\
\hline 1 & Hopwood Anthony G. & 277 & 219 & 88 & 584 \\
2 & Miller Peter & 186 & 275 & 116 & 577 \\
3 & Foucault Michel & 127 & 85 & 71 & 283 \\
4 & Power Michael & 38 & 110 & 108 & 256 \\
5 & Latour Bruno & 47 & 126 & 61 & 234 \\
6 & Kaplan R. S. & 87 & 97 & 46 & 230 \\
7 & Merchant K. A. & 87 & 115 & 28 & 230 \\
8 & Brownell P. & 116 & 87 & 2 & 205 \\
9 & Chua W.F. & 59 & 86 & 45 & 190 \\
10 & Covaleski M.A. & 72 & 76 & 41 & 189 \\
11 & Giddens Anthony & 54 & 78 & 51 & 183 \\
12 & Burchell S. & 88 & 63 & 30 & 181 \\
13 & Cooper DJ & 79 & 53 & 48 & 180 \\
14 & Simons R. & 44 & 100 & 35 & 179 \\
15 & Chenhall R. H. & 32 & 100 & 38 & 170 \\
16 & Robson K. & 42 & 80 & 36 & 158 \\
17 & Meyer J.W. & 88 & 41 & 28 & 157 \\
18 & Hofstede G. & 86 & 56 & 5 & 147 \\
19 & Roberts J. & 48 & 60 & 32 & 140 \\
20 & Watts R.L. & 90 & 36 & 13 & 139 \\
\hline
\end{tabular}

\section{Conclusions}

The structure of the accounting research has been examined in the content of the AOS journal. Studies published in the AOS journal over the last 25 years during the period of 1990-2014 are examined historically. The main purpose of the study is to determine the main characteristic structure of the accounting research in the last quarter by analyzing the articles published in the AOS journal during the last 25 years. Such an assessment of the situation contributes to understand recent developments in international accounting literature, to determine the interaction between accounting and other disciplines and to understand the general trends in accounting research. Most cited studies in the AOS journal point to the years of the 1980s as a publication date. Books like Science in Action, The Constitution of Society, and Psychometric Theory show the multi-disciplined characteristic of the AOS journal.

The results of the study showed also that science of management journals has a particular weight on the studies of this journal. As a result, six of the 20 journals in the list are leading journals in the management of science (Administrative Science Quarterly, Harvard Business Review, The Academy of Management Journal, Strategic Management Journal, Academy of Management Review, and Journal of Applied Psychology). The American Journal of Sociology is the most cited sociology journal by the AOS journal. This situation confirms that the journal is operating according to its primary mission.

This study is limited to determine the most cited articles and journals in the AOS journal during the last 25 years by 
conducting citation analysis taking into account the weightings. This study is part of a larger research program. As part of ongoing research, the Financial Times listed the best 45 journals for business schools and an accounting field related journal was chosen. Bibliometric analysis will be conducted for the citations of the studies published in these journals. These journals are Accounting, Organizations and Society; Accounting Review; Contemporary Accounting Research; the Journal of Accounting and Economics; the Journal of Accounting Research and Review of Accounting Studies'. In further studies, articles from these journals can be examined from the beginning of their publication with citation and co-citation analysis.

\section{References}

Abbott A. (1988). The System of Professions: An Essay on the Division of Expert Labor. By Chicago: University of Chicago Press.

Acedo, F. J. \& J.C., Casillas. (2005). Current Paradigms in the International Management Field: An Author Co-Citation Analysis. International Business Review, 14(5), 619-639. http://dx.doi.org/ 10.1016/j.ibusrev.2005.05.003

Al, U. \& Tonta, Y. (2004). Citation Analysis: Sources Cited in Dissertations Completed at Hacettepe University Department of Librarianship. Bilgi Dünyasl, 5 (1), 19-47.

Al, U. (2008). Scientific Publication Policy of Turkey: A Bibliometric Approach Based on Citation Indexes, PhD Dissertation, Ankara University, Ankara.

Armstrong P. (1985). Changing Management Control Strategies: The role of competition between accountancy and other organizational professions. Accounting, Organizations and Society, 10(2), 129-148. http://dx.doi.org/10.1016/0361-3682(85)90012-1

Armstrong P. (1987). The Rise of Accounting Controls in British Capitalist Enterprises. Accounting, Organizations and Society, 12(5), 415-436. http://dx.doi.org/10.1016/0361-3682(87)90029-8

Armstrong, P. (1994). The Influence of Michel Foucault on Accounting Research, Critical Perspectives on Accounting, 5(1), March 1994, 25-55. http://dx.doi.org/10.1006/cpac.1994.1003

Barca, M., (2005). Evolution of Strategic Management Thinking: A Story about Formation of A Scientific Discipline, Management Research Journal, 5(1), 7-38.

Bonner, S., Hesford, A., Stede, W.A. \& Young, M.S. (2006). The Most Influential Journals in Academic Accounting. Accounting, Organizations and Society, 31(7), 663-685. http://dx.doi.org/10.1016/j.aos.2005.06.003

Brown, L. D. \& Gardner, J. C. (1985). Applying Citation Analysis to Evaluate the Research Contributions of Accounting Faculty and Doctoral Programs. Accounting Review, 60(2), 262.

Brown, L. D. \& Gardner, J. C. (1985). Using Citation Analysis to Assess the Impact of Journals and Articles on Contemporary Accounting Research (CAR). Journal of Accounting Research, 23(1), 84-109. http://dx.doi.org/10.2307/2490908

Brown, L. D., Gardner, J. C. \& Vasarhelyi, M.A. (1987). An Analysis of the Research Contributions of Accounting, Organizations and Society, 1976-1984. Accounting, Organizations \& Society, 12(2), 193-204. http://dx.doi.org/10.1016/0361-3682(87)90006-7

Burchell, S, Clubb, C., Hopwood, A., Hughes, J. \& Nahapiet, J. (1980). The Roles of Accounting in Organizations and Society. Accounting, Organizations and Society, 5(1), 5-27. http://dx.doi.org/ 10.1016/0361-3682(80)90017-3

Burchell, S. Colin Clubb, Anthony G. Hopwood. (1985). Accounting in its Social Context: Towards A History of Value Added in The United Kingdom. Accounting, Organizations and Society, 10(4), 381-413. http://dx.doi.org/10.1016/0361-3682(85)90002-9

Chan, K.C. \& Liano, K. (2009). Threshold citation analysis of influential articles, journals, institutions and researchers in accounting. Accounting and Finance, 49(1), 59-74. http://dx.doi.org/10.1111/j.1467-629X.2007.00254.x

Chan, K.C., Chan, K.C., Seow, G.S., Tam, K. (2009). Ranking Accounting Journals Using Dissertation Citation Analysis: A Research Note. Accounting, Organizations \& Society, 34(6), 875-885. http://dx.doi.org/10.1016/j.aos.2008.12.002 
DiMaggio, P.J \& Powell, W.W. (1983). The Iron Cage Revisited: Institutional Isomorphism and Collective Rationality in Organizational Fields. American sociological review, 48(2), 147-160.

Foucault, M. (1977). Discipline And Punish: The Birth of The Prison, New York, Random House.

Giddens A. (1986). The Constitution of Society, University of California Press.

Gökkurt, B., Ö. (1998). Citation Data and Infor metrics Laws: An Application in Doctoral Theses to the Turkish Librarianship, Turkish Librarianship, 12(1), 21-32.

Hatch, Mary J. \& Cunliffe, Ann L. (2006). Organization Theory: Modern, Symbolic, and Postmodern Perspectives, Oxford: Oxford University press.

Hofstede, G. (1980). Culture's consequences: international differences in work-related values, Sage Publications.

Hofstedt, T. R. (1976). Behavioral Accounting Research: Pathologies, Paradigms and Prescriptions. Accounting, Organizations \& Society, 1(1), 43-58. http://dx.doi.org/10.1016/0361-3682(76)90006-4

Hopwood Anthony G. (1987). The Archeology of Accounting Systems. Accounting, Organizations and Society, 12(3), 207-234. http://dx.doi.org/10.1016/0361-3682(87)90038-9

Hoskin K.W., Macve R. H. (1986). Accounting And The Examination: A Genealogy Of Disciplinary Power. Accounting, Organizations and Society, 11(2), 105-136.

Just, A., Schäffer, U., \& Meyer, M. (2009). The intellectual structure of accounting research-A bibliometric analysis. Working paper, Beisheim School of Management.

Justesen L. and Jan M., (2011). Effects of Actor-Network Theory in Accounting Research, Accounting, Auditing \& Accountability Journal, 24(2), 161 - 193. http://dx.doi.org/10.1108/09513571111100672

Keith, R. (1992). Accounting Numbers as "Inscription": Action at A Distance and the Development of Accounting. Accounting, Organizations and Society, 17(7), October $\quad 1992, \quad 685-708$. http://dx.doi.org/10.1016/0361-3682(92)90019-O

Latour B. (1987). Science in Action: How to Follow Scientists and Engineers through Society, Harvard University Press, 1987, 274.

Lawrence A. Gordon, V.K. Narayanan. (1984). Management Accounting Systems, Perceived Environmental Uncertainty and Organization Structure: An empirical investigation. Accounting, Organizations and Society, 9(1), 33-47. http://dx.doi.org/10.1016/0361-3682(84)90028-X

McRae, T. W. (1974). A Citation Analysis of the Accounting Information Network. Journal of Accounting Research, 12(1), 80-92. http://dx.doi.org/10.2307/2490529

Meyer, J.W. \& Rowan, B. (1977). Institutional Organizations: Formal Structure as Myth and Ceremony. American Journal of Sociology, 83, 340-363.

Miller, P., Ted O'Leary. (1987). Accounting and the Construction of The Governable Person. Accounting, Organizations and Society, 12(3), 235-265. http://dx.doi.org/10.1016/0361-3682(87)90039-0Nunnally, J. C. and Bernstein, I.,H., (1978). Psychometric Theory, McGraw-Hill; 3rd edition

Özen Ş. (2007). New Organizational Theory: New Horizons and Problems in Organizations, “Organizational Theories" Sargut, A.S. and Özen, Ş. (Ed.), Ankara: İmge Kitapevi.

Peng, M. W. \& Zhou, J. Q. (2006). Most cited articles and authors in global strategy research. Journal of International Management, 12 (4), 490-508. http://dx.doi.org/10.1016/j.intman.2006.04.001

Podsakoff, P. M., MacKenzie S.B., Podsakoff N. P. \& Bachrach D.G. (2008). Scholarly Influence in the Field of Management: A Bibliometric Analysis of the Determinants of University and Author Impact in the Management Literature in the Past Quarter Century. Journal of Management, 34(4), 641-720. http://dx.doi.org/10.1177/0149206308319533

Preston MA., David J. Cooper, Rod W. Coombs. (1992). Fabricating budgets: A study of the production of management budgeting in the national health service. Accounting, Organizations and Society, 17(6), August 1992, 561-593. http://dx.doi.org/10.1016/0361-3682(92)90014-J

Sarfatti, M. (1977). The Rise of Professionalism, University of California Press.

Solomon, I. \& Trotman, K. T. (2003). Experimental judgment and decision research in auditing: the first 25 years of AOS. Accounting, Organizations \& Society, 28(4), 395-412. http://dx.doi.org/10.1016/S0361-3682(02)00023-5 
Tahai, A., Rigsby, J.T. (1998). Information Processing Using Citations to Investigate Journal Influence In Accounting. Information Processing \&Management, 34(2), 341-359. http://dx.doi.org/10.1016/S0306-4573(97)00082-4

Verbeek, A., K., Debackere, M., Luwel \& E. Zimmermann. (2002). Measuring Progress and Evolution in Science and Technology - I: The multiple uses of bibliometric indicators. International Journal of Management Reviews, 4(2): 179-211. http://dx.doi.org/ 10.1111/1468-2370.00083

Watts, Ross L; Zimmerman, J., L. (1986). Positive Accounting Theory, Prentice-Hall Inc.

\section{Notes}

Note 1. This study was presented as a draft paper at the 11th. International Accounting Conference held in İstanbul between the dates of 31 October and 2 November 2014.

Note 2. "Author Information Pack". Retrieved 13 January 2014.

http://www.elsevier.com/wps/find/journaldescription.cws_home/486?generatepdf=true (31.07.2014)

Note 3. Financial Times Top 45 Journals

https://library.mcmaster.ca/find/ft-research-rank-journals (31.07.2014)

Note 4. 1) 1990-1999; $\quad$ 2) 2000-2009; $\quad$ 3) 2010-2014

Note 5. Rankings of the studies according to citations

Note 6. General Database Total Citations 